nent successful business man who, like many other business leaders, became actively interested in education and finally emerged as a social philosopher and statesman. Business may well take pride in such men. But since much of their public life depends directly upon their success in business activities, may we not reasonably expect their biographers to devote considerable care and attention to the business aspects of their life work? The founder of Brookings Institution had a remarkable business career which is interesting for its own sake and deserving of more detailed and accurate research than it has received in this book. Even so, it is good to have another piece of evidence that not all business men are the predatory, antisocial monsters that are so often described to us today. Illustrations, brief bibliography, and index.

Ruth Prince Mack, Controlling Retailers. New York: Columbia University Press, 1936. Pp. 551. \$4.50. Sub-titled A Study of Cooperation and Control in the Retail Trade with Special Reference to the NRA. A careful and intelligent attempt to appraise one part of a large-scale effort to organize American industry on a self-regulatory basis. Part I deals with the situation before the NRA, Part II with the genesis of the Code, Part III with the Code Administration, Part IV with retail trade under the NRA. The author's general conclusions are given at the end, the main one being that "the operation of the Retail Code . . . did not substantially further the public interest" (p. 497). Index.

Vernon G. Setser, The Commercial Reciprocity of the United States, 1774 1829. Philadelphia: University of Pennsylvania Press, 1937. Pp. xi, 305. $\$ 3.00$. A scholarly study of the commercial diplomacy and legislation of the United States for the period indicated, analyzing objectives, principles, circumstances, and results. Excellent bibliography and index.

\title{
In SiDemoríam
}

The Society has recently lost through death four members of long standing: William Morgan Butler and Gordon Dexter of Boston, Dean William R. Gray of the Amos Tuck School of Dartmouth College, and Charles Hayden of New York. Each was prominent in his respective field and each will be sadly missed.

William Morgan Butler was born in New Bedford, Massachusetts, January 29, 1861. Like many another Yankee boy, he rose from poor circumstances through his own tireless efforts. Starting as a newspaper and delivery boy and moving on to positions of greater responsibility, he saved enough money to pay tuition in law at Boston University from which he received the LL.B. in 1884. His law practice led him into both politics and business. In the 1890's he rose from local New Bedford political offices to the House and then the Senate of Massachusetts. In 1923 he entered national 
politics when Coolidge became President, serving first as a member of the Republican National Committee, then as pre-convention campaign manager for Coolidge, later as Chairman of the Republican National Committee, and finally as United States Senator to fill the vacancy caused by the death of Henry Cabot Lodge. Meanwhile he had acquired large industrial interests which included the Butler Mills, the Quisett Mills, the Hoosac Mills, the New Bedford Cotton Mills, the Consolidated Textile Company, and the West End Thread Company. He had also served as executive in the Atlas Tack Company, the Boston \& Worcester Electric Companies, the Columbian National Life Insurance Company, the Merchants National Bank, and the New Bedford Storage Warehouse Company. As receiver for the Hoosac Mills, Mr. Butler began the suit which terminated in the Supreme Court decision against the AAA. He died on March 29, as a result of an injury received in a fall.

Gordon Dexter, who died at Nassau, Bahamas, on March 11, was born in Beverly, Massachusetts, August 12, 1864. He was graduated from Harvard University in 1887. At the time of his death he was clerk and director of the Hunt-Spiller Manufacturing Corporation, and a director of the Mexican Northern Mining \& Railway Company, the Submarine Signal Company, and the Submarine Signal Corporation. He was also a prominent yachtsman and clubman. In $1927 \mathrm{Mr}$. Dexter gave the Society one of the most valuable lots of historical records which are now in its possession-27 bound volumes and 74 boxes of unbound manuscripts relating to William Appleton \& Company, known after 1860 as Samuel Hooper \& Company, of Boston, covering far-flung commercial activities for the period 1840 to 1889 .

William R. Gray, since 1919 dean of the Amos Tuck School at Dartmouth College, died on March 31 after several months of illness. Born in Aurora, Illinois, September 27, 1879, he served for several years as a clerk in the United States Treasury before going to Dartmouth College where he received his bachelor degree in 1904 and a master's degree in commercial science in 1905. He had been connected since 1905 with the Amos Tuck School, the second oldest business school in the United States, first as instructor in accounting, and then as assistant professor, then acting director of the School (1917-19), and subsequently as dean. At the time of his death he was director of the Connecticut River Power Company and a trustee of Dartmouth College, Holderness School for Boys, and the Protestant Episcopal Diocese of New Hampshire, 
Charles Hayden, who died in New York on January 8, 1937, had risen to such a position of prominence in business that former Ambassador James W. Gerard named him in 1930 as one of the 64 rulers of the United States. Born in Boston July 9, 1870, he graduated from Massachusetts Institute of Technology in 1890, and after a year of travel abroad he entered the field of banking in which he worked for the rest of his life. In 1892, with Galen L. Stone, he formed the private banking firm of Hayden, Stone \& Company. By 1936 he had risen to positions as officer or director in seventy corporations. His business interests covered an extraordinarily wide range, including railroads, express companies, steel, coal, baking, textiles, locomotives, chemicals, mining, oil, truck manufacture, banks, and shipping. He was also a director of the Metropolitan Opera Association, and life member of the Corporation of Massachusetts Institute of Technology. During his lifetime Mr. Hayden had made many large public benefactions, including the $\$ 150,000$ planetarium of the American Museum of Natural History in New York and a valuable plot of land for the Boys' Club of New York, and his will created a foundation of $\$ 40,000$,000 , for the education and assistance of boys and young men. To say nothing of his contribution to efficient business administration, by this magnificient gift Mr. Hayden, like many another business man, has made private profits yield a rich return to society and posterity.

\section{Secretary's Column}

Since the publication of the last Bulletin the Society has received and gratefully acknowledges the following acquisitions:

From American Petroleum Institute, New York City: Proceedings, Seventeenth Annual Meeting American Petroleum Institute: Sec. 1, General Sessions; Sec. II, Marketing; Sec. III, Refining; Sec. IV, Production (Chicago, Nov. 9 to 12, 1936).

From Miss Cornelia Duren, Oakland, California: papers belonging to the estate of Warren Duren of Lexington, Massachusetts: various property deeds, 1814-69; tax bills in the town of Woburn, 1845-49; five fire insurance policies, 1846-54; memorandum book of farm produce sold in Woburn, 1831-39.

From Mr. Courtland C. Earle, Groton, Massachusetts: A Catalogue of the Machine Shop Plant of the Phenix Iron Foundry of Providence, $R . I$. (Lowell, 1903).

From Henry E. Huntington Library and Art Gallery, San Marino, California: Ninth Annual Report, 1935-1936; Huntington Library Publications, 1937. 